\title{
Effects of Graphics and Computer Aided Design Software on the Production of Embroidered Clothing in South Western Nigeria
}

\author{
Bolajoko Esther Adiji, Tope Israel Ibiwoye \\ Federal University of Technology, Akure, Nigeria \\ Email: preciousdiji@yahoo.com, topibiwoye@yahoo.com
}

How to cite this paper: Adiji, B. E., \& Ibiwoye, T. I. (2017). Effects of Graphics and Computer Aided Design Software on the Production of Embroidered Clothing in South Western Nigeria. Art and Design Review, 5, 230-240.

https://doi.org/10.4236/adr.2017.54019

Received: August 23, 2017

Accepted: November 17, 2017

Published: November 21, 2017

Copyright ( 92017 by authors and Scientific Research Publishing Inc. This work is licensed under the Creative Commons Attribution International License (CC BY 4.0). http://creativecommons.org/licenses/by/4.0/

\begin{abstract}
Computer graphics has played significant role in design concept of most fields of Visual Art. Embroidered design on paper and other forms of textile materials are not exempted. Embroidery art has a long standing history of embellishment on textile material, many of which are first drawn on paper and later transferred unto the textile material or sometimes drawn directly on the textile material before commencing the embroidery usually done manually with thread and needle. Just like many fields and discipline, the advent of computer technology also has its influence on the practice of embroidery. This paper therefore assesses the effect of computer graphics on the production of embroidered clothing in selected cities of south western Nigeria. A concise survey was carried out in the study area to assess the impact of computer graphics on embroidered clothing.
\end{abstract}

\section{Keywords}

Computer Graphics, Embroidery, Textiles Design, CADS

\section{Introduction}

Visual Arts are art forms that are primarily visual in nature, such as painting, photography, textiles, printmaking, sculpture, ceramics, etc.; the people who studied any of these forms of visual arts are regarded as Visual Artists (Ibiwoye et al., 2014). Embroidery design is a form of Visual Art categorised under Textiles Design. The history of Visual Art in Nigeria can be traced backed to the Nok art; the art of the people believed to have lived between 900 B.C and 200 B.C in what is now the North Central Nigeria. The art of the earlier Ife Kingdom in the South-Western Nigeria was also very unique (Blier, 2005). 
Oladumiye (2003) notes that Visual Art is a form of art that seeks to present the variety of ideas and emotions as recorded by the creative artist, and communicated to the audience through variety of visual and representation media. Graphics being a form of visual "writing" has helped to paint pictures of intentions or concepts. Graphic design as a means of visual communication has also aided the manner in which designs concepts are presented for adequate communication. The process of designing, however had been laborious before the advent of computer as it does involve a number of artists having to work several hours to produce a piece of an embroidered design. The process becomes more hectic for mass production. Consequent upon the advent of computer technology and evolving Computer Graphics practice, embroidery designers are able to make use of Computer Aided Design, CAD to create varieties of their embroidery design within limited time space. This feat is not limited to embroidery design but virtually all of Visual Art disciplines.

Researches in embroidery practice among the people of South-Western Nigeria, according to Adiji (2016) have been scanty. The research into embroidery practice however ought to be continuous; as the trendy nature of fashion is dynamic, so are its concepts that constitute the trend. Mogg (2000) observes that each embroidered piece indicates its own time, taste, and the prevalent styles. Some of the researchers that have carried out studies on embroidered clothing include; Osunfisan (1971) who researched into dress embroidery in Kano city, Nigeria with the objective of documenting the various stitching applicable on men's dresses. Heathcote (1979) examined the Sudanese influence on Hausa embroidered clothing; Ogunduyile (1985) also studied the aesthetic and symbolic aspects of Hausa caps and garments, with a view to appreciating the values often attached to the crafts. The studies revealed understanding of symbols as a medium of cultural expressions in the Hausa culture. These previous studies failed to consider the effect of the latest technology in the production of embroidered design. The use of graphics and CAD was completely left out.

This write therefore seeks to accentuate the unpublished work of Adiji (2016) which assessed the embroidery production on textile garments from selected cities in south-western Nigeria. The study notes that the earlier studies did not consider the interrelationship between hand embroidery, and machine made embroidery brought about as fallout of technology on the production of embroidered clothing in South-Western Nigeria. The study therefore went further to assess the level of computer usage in embroidery practices among the practitioners in South-Western Nigeria, as well as explore its effect on embroidery patronage. This write up further throw lighter on not just the benefits of machine made embroidery, or its preference to handmade embroidery, but on the technology involve in achieving a better embroidery design within a short time. The significance of Computer Graphics as aided by CAD in aiding a better practice of embroidery cannot be overemphasized. Being a traditional culture, the sustenance of embroidery practice should be addressed in the context of latest technology for it to remain relevant and sustained. The outcome of the study 
may further enhance the perception of embroiderers about the significance of Graphics and CAD on embroidery practice.

Adiji (2016) notes that contemporary Yoruba embroideries have began to progressively modify their motifs as a result of western ideas and technology, making use of Computer, Graphics. As in most fields of endeavour, Computer Graphics has helped in making explicit design concept of patterns to be embroidered on textile garment. The Computer Graphics, in its bid to make designing and drawing of pattern more convenient has welcomed the use of Computer Aided Design Software, CADS. The beauty and the advantage of CADS isthat several varieties of design concepts with different orientations and colour swatches could be achieved within a short space of time.

Although virtually every society in the South-Western Nigeria has its own kind of decorative motif that is of value to it, the contemporary development of embroidery in the part of the country has been in the direction of embroidery made on woven fabric such as (aso-oke), batik, tie-dye and akwete. The type of textile material embroidery is produced on notwithstanding, a Designer, particularly an industrially biased one is always conscious of the mass production possibility of a design concept. The use of machine now become spertinent. Embroidery through machine has absolutely transformed the demand for embroidery designed products such as clothing and fashion accessories both locally and internationally. Machine embroidery is usually convenient and better executed when the design is done using the computer with aid of computer graphics software. Akinwumi (1998) and Adiji (2016) observe that machine embroidery designs involve the use of advanced techniques that render application like automatic digitizing 3-dimentional effects and multiple sequencing. This software ensures fine finishing and elaborate designs, thereby increasing the commercial value of embroidered products (Akinwumi, 1998; Adiji, 2016).

The foregoing further suggests that as more emphases are being laid on machine made embroidery, attention must be drawn to CADS such as Pattern Maker Deluxe, Flictex Pro, Weave It, I weave it, and Grid 'N Weave it are used to drive the execution of embroidery design for machine production. This become important eliminates or at worse reduces the inconsistency caused by semi-automation of embroidery production where design for machine production is manually done. Figure 1 is an example of an embroidery design being done by a machine. The design was manually drawn on a paper and then traced on the fabric before the machine began working on the fabric.

In automated embroidery production the machines are often computer controlled and specifically conditioned for embroidery. These industrial-commercial embroidery and combination sewing machines are driven by computers that read digitized embroidery design files created by special software. These machines are special purpose sewing machines that produce elaborate embroidery on fabrics by following a computer design can either be computer-created or created by the designer (Lemon, 2004). These design patterns come in various 


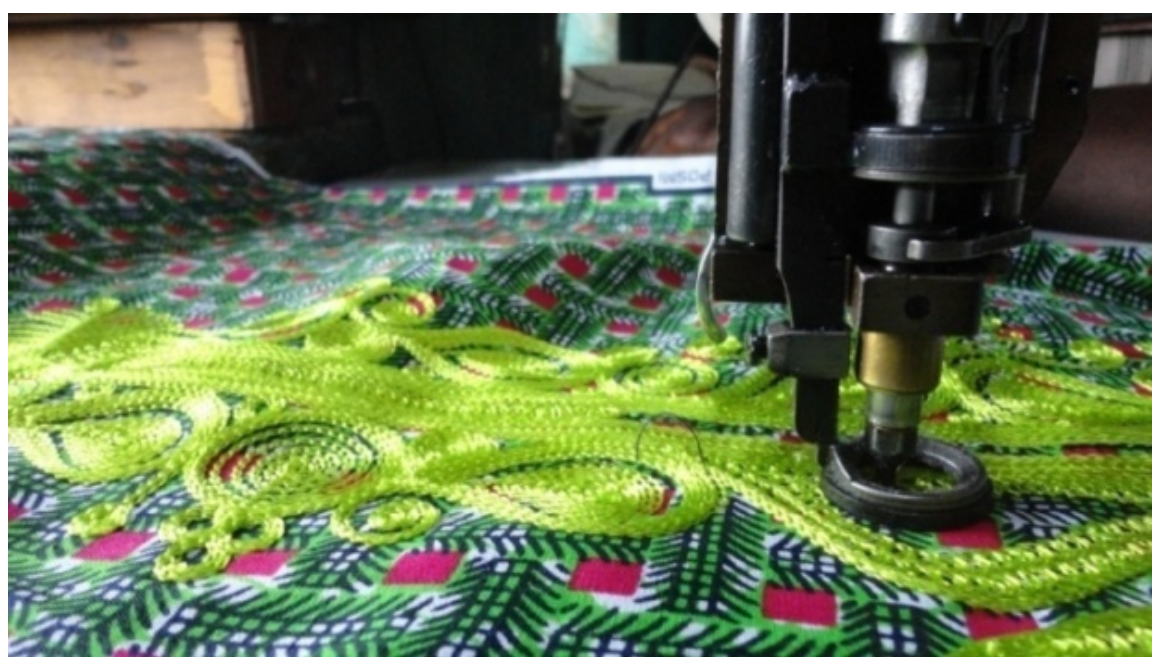

Figure 1. An embroidery design on coil embroidery. Source: machine Source: Adiji (2013).

pattern templates, or as clipart. Lemon (2004) adds that a more recent innovation in home sewing embroidery was first commercially available in the 1990s.

\section{Computer Graphics and Computer Aided Design Software CADS}

Computer graphics is an art of drawing pictures on computer screen with the help of programming. It is a discipline that involves the skilful generation of images through the creation, manipulation, and computation of data (Tutorials Point, 2015). Williams \& Agbo (2013) observe that there is barely a field of human activity today that has not felt the impact of the dramatic changes in Information and Communication Technology, ICT in the last $10-15$ years. The fields of Clothing and Textiles have continued to experience their fair share of the influence of ICT in their operations. It has also been noted that an appreciable number of developed nations such as United States of America, France, and China, have grown their economies through the fashion and textiles industries (Biney-Aidoo \& Antiaye, 2013). These industries can therefore be counted as strong economic forces to be reckoned with in the development of a nation when given the required attention right from the training institutions before students get into the labour world (Adiji, 2016).

The acronym CAD is Computer Aided Design while CADs is Computer Aided Design Software. The term 'Computer Aided Design-CAD' could implies the use of computer technology to carry out or assist the design process. A CAD system is an information technology hardware; a specialized software which may have a particular area of application. It could also be peripherals which in certain applications are quite specialized (Bilalis, 2000).

Prior to the advent of CAD software, design sketches were made on paper with the aid of T-squares, set-squares, French curves, compass, pencils, erasers and a specialized drawing table. Designs sketches of are often hand-drawn; this 
requires skills mastery in the mechanics of drawing lines in relation to the actual measurement, with precision, accuracy and attention to detail (Trika, 2016). The process could be cumbersome and laborious. This however do not suggest that the use of CADs may completely expunge the need for hand-drawn preliminary design sketches, but it is advantageous in the sense that CAD assist in modifying a drawing or correcting mistakes without necessarily starting all over again. It is also important to note that the invention of the graphic tablet, a peripheral of the computer system does not totally erase the input of user in the drawing activities. This implies that the user must have basic knowledge of design principle and simple drawing skills to put the gadgets to adequate use. It is usually comfortable when designing with CADs. Although Leach (2002), opines that it may be faster to create a 'rough' drawing such as a sketch by hand (pencil and paper) than using Computer Aided-Design (CAD), however, for larger and more complex drawings which involve similar shapes or repetitive operations, CAD method is more efficient. This assumption may not be correct, giving the advent of the Graphic Tablet that is usually accompanied with light pen, used in drawing on the tablet. The user views the pattern or design on the computer monitor as the drawing is made, and necessary corrections are made using drawing tools in the CADs to perfect the drawing. The drawn patterns are printed out on paper when completed, and transferred on the garment to be embroidered.

Production in the fashion industry before the advent CAD software was usually carried out by a team of workers each with specific job description. The whole process was time consuming due to repetitive work involved at every stage of production, particularly when intricate patterns are to be drawn out. Patterns are now easily drawn out with the aid of CADs and better still, there are software with pattern template from which the Designer could pick from.

Due to costs associated with maintenance, import fees and norms, as well as cost for adequately training personnel on the machine operations, the spread of automation is still limited in the developing world. This is not unconnected with the cost of procuring the machine, and other paraphernalia expenditures that are more expensive than the cost of procuring labour for manual process. Despite the challenge, Computer Aided Design, CAD and/or Computer Aided Manufacturing, CAM systems have spread in developing countries such as Thailand and Sri Lanka (UNIDO, 1993; Wijayasiri \& Dissanayake, 2008).

Advances in technological have rubbed off on the clothing industry, particularly in developed countries. The innovation birthed by the new technologies include smart fibres (i.e. clothing with integrated electronics as a main feature), fibre surface coatings (i.e. coatings applied to make clothing flame retardant, water resistant, antimicrobial, etc.), radio frequency identification chips (i.e. tags applied to clothing to improve stock accuracy and product availability, and that might become useful as a tool for theft prevention or anti-counterfeiting), and biodegradable clothing (i.e. clothing produced from banana leaves, corn and bamboo), among others. Both the textile and clothing industries also use tech- 
nological innovations generated in the chemicals industry, such as complex man-made fibres (OECD, 2004; Madsen et al., 2007).

\section{Importance of Computer Aided-Design (CAD) in Fashion}

The three fields of Fashion Design namely, Clothing technology, Textiles technology, and Fashion illustration are CAD dependent in the modern day fashion designing. Fashion Design Technology is the development of skills to identify and generate ideas and investigate into the manufacturing of clothing and accessories. This vital role is performed by the fashion designer. The area a fashion designer covers may range from the prediction or generation of the next trend choice of pattern cutting and responsibility for the finished sample (Aldrich, 1997). The process of ideation and actualisation is clearly enhanced by the help of CAD as various idea or concept can be troubleshot easily with the aid of a CADs until the desired pattern is achieved.CAD as a tool used for design and drafting activity, can also be used to make rough idea sketch although it is more suited to create accurate finished drawing. CAD has powerful tools which aid creativity and visualization (Leach, 2002).

Photoshop is a commercial standard image editing software. In Fashion, it can be used for editing and correcting digital photos and preparing images for $\mathrm{mood} / \mathrm{story}$ board, magazines and posters. It can be used to create designs for wall hangings and print designs for fabrics and 'Tee' shirts. Photoshop is also employed to create basic patterns, figures, simple garments and garment features with the aid of grids and guides. Digital design portfolio is created with the aid of Photoshop which provides visual evidence of capabilities, strengths and qualities. Digital portfolio allows students to send their work to any part of the world (Burke, 2006).

\section{Computer Aided Embroidery Design in Nigeria}

Andreadis, lampridou and Sherar (2015) noted that, Josue Heilmann created the first hand embroidery machine in the year 1828 . This machine was able to utilize up to 4 hand embroideries, and signaled the start of revolution in embroidery. Although traditional hand embroidery has a long history of several thousand year, long before the advent of machine embroidery which is about 2 centuries old. Embroidery machines are now both single-head and multi-head, fitting in to 56 heads. As each head fits one thread colour, this implies that the number of heads determine the amount of colours that would be featured in an embrodiery without interrupting the machine's function. The advent of machine did not only give birth to textile designer who created patterns for embroidery but with the advent of digital technology also birthed the CADs that are now used by embrodiery machines. The design softwares were to specifically developto serve various embroidery requirements. This breakthrough according to Adiji (2016) has boosted the embroidery production as a new revolution of CADS has began in the embroidery industry. 
As the machines becomes more expensive, due to advancement in technology users who could not afford the machine then had to rely on purchasing the software that works with digital input to transform a picture or artwork into a machine readable embroidery pattern that can be used on embroidery machine Lemon (2004) and Adiji (2016). Embroidery sewing machine with inbuilt patterns (Figure 2) became commercially available in the nineties the inbuilt design pattern in them are accessible by users are, similar to computer programmes.

Computer Aided Design can be defined as the use of computer technology for design of objects, real or virtual to achieve precise drawing, however the computer programme written to achieve this feat are known as software. The resulting drawings from the use of the software contain symbolic information such as the materials, the processes, the dimensions and the tolerance, according to application specific conventions. Computer Aided Design is also utilized by the embroidery industry in order to improve the embroidery designs (Anderadis et al., 2015). Bidwell (2009) opines that there exist various commercial and free software products that enable the designing and editing of embrodiery patterns and images. The purpose of the design embroidery software is to translate the drawing made in the computer into stiches, and executed by the embroidery machine. Most of the embroidery design softwares that had been developed can be used for private, commercial and the industrial embroidery needs. The soft wares usually have advanced users interfaces with sophisticated functions. The user can create a drawing, set up the number of stitches, define the type of stiches, that is, satin, run fill stiches, it will select colours and edit the design. There

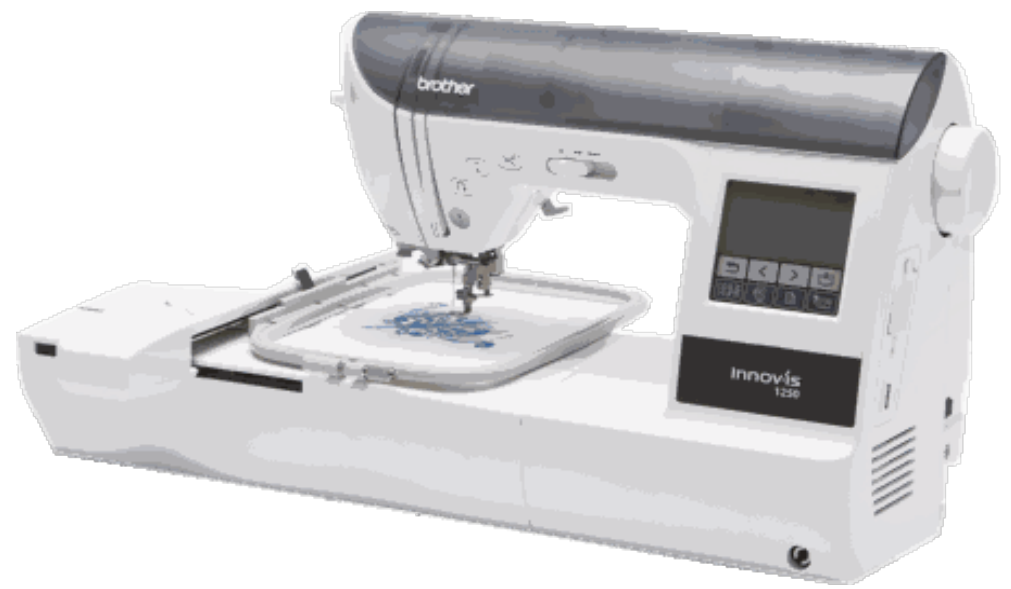

Figure 2. CAD enabled automated embroidery machine. Source: https://search.yahoo.com/search;_ylt=AwrBT.IaBvtZ82MA_QpXNyoA;_ylc =X1MDMjc2NjY3OQRfcgMyBGZyA3locy1pbnZhbGlkBGdwcmlkA0pCR1 RUM3MyU3FTR1F3WDVONzdkaEEEb19yc2x0AzAEbl9zdWdnAzEEb3Jp Z2luA3NlYXJjaC55YWhvby5jb20EcG9zAzAEcHFzdHIDBHBxc3RybAMw BHFzdHJsA-

zYxBHF1ZXJ5A3BpY3R1cmVzJTIwb2YlMjBlbmFibGVkJTIwJTIwYXV0b2 1hdGVkJTIwZW1icm9pZGVyeSUyMG1hY2hpbmUEdF9zdG1wAzE1MDk $\underline{2 \mathrm{MjMzNjE}-? \mathrm{p}=\text { pictures+of+enabled++automated+embroidery+machine }}$ (2016) 
are also more compliated functions, which include the import images to the software and their digitalization, offering all the main attributes of the images processing.

Furthermore, some of the embroidery design software solutions offer lettering functions. These functions are aimed at automatically converting type fonts into stitches. In this way, a font character can be embroidered. It is believed that the emergence of computerized embroidery in fashion industry was consequent upon the agitations by factory workers, or embroiders who made use of manual process of hand and needle/thread in fashion industry which eventually led to the invention of embroidery sewing machine (Wing, 2010). Full automated embroidery production may be achieved where there are modern embroidery machines loaded with digitised design pattern with computer systems loaded with the required software and connected to embroidery machine. Computerized embroidery is therefore the automation of the embroidery machine operation, which is mostly controlled by the accurate computer instruction to create high quality and standardized embroidery design. Embroidery production is quite laborious if it has to be carried out traditionally, especially when operating in a large scale. Embroidery machine manufacturing industry has however, with the help of CADs and embroidery machines ameliorated the labour intensive processes of embroidery production through the computer. And furthermore, due to well organised and precise design and production process, production cost and other paraphernalia cost is reduced. Consequent upon these advantages, computerized embroidery is most favoured in the fashion indsutry.

Nowadays, familiarisation of Fashion Designers towards computerised embroidery is well used by some international fashion brands to add value to designs. It is beleived that the local designers are not familiar with the techniques. Nigeria Fashion Designers, especially the older generation seldom use computerised embroidery activities in their designs. However the younger generation is beginning to embrace CADs particularly while trying to meet the requirements of employers or customers (Adiji, 2016).

In a survey carried out by Adiji (2016) in some selected cities in the South Western Nigeria, out of the total number of two hundred and fifty (250) questionnaires administered to the designers of embroidery in the study areas, two hundred and thirty five (235) representing 94\% of the total number administered were returned and used for the analysis. The questionnaires were administered to the respondents in Oyo, (Oyo State) Abeokuta (Ogun State) and Akure (Ondo State) with the help of field assistants in the various cities

The study reveals that there are two types of embroiderers based on the method used. The machine embroiderers constituted a greater proportion 185 (78.72\%) while only 50 (21.28\%) utilizes hand as a method of embroidery. the result shows that embroiderers have started to embrace innovative technology for their work. Meanwhile, respondents from Akure 28 (37.33\%) makes use of hand embroidery while respondents based in Abeokuta 80 (89.23) preferred machine embroidery for their work as evident in Table 1. 
Table 1. Types of embroidery practices by respondents.

\begin{tabular}{ccccccccc}
\hline \multirow{2}{*}{$\begin{array}{c}\text { Types of } \\
\text { embroidery }\end{array}$} & \multicolumn{2}{c}{ Abeokuta } & \multicolumn{2}{c}{ Oyo } & \multicolumn{2}{c}{ Akure } & \multirow{2}{*}{ Total } & Cum. \% \\
\cline { 2 - 7 } & Freq. & $\%$ & Freq. & $\%$ & Freq. & $\%$ & & \\
\hline Hand & 7 & 10.77 & 15 & 15.79 & 28 & 37.33 & 50 & 21.28 \\
Machine & 58 & 89.23 & 80 & 84.21 & 47 & 62.67 & 185 & 78.72 \\
Total & 65 & 100.00 & 95 & 100.00 & 75 & 100.00 & 235 & 100.00 \\
\hline
\end{tabular}

Source: Field Work, Adiji (2016).

Table 2. Effects of modern technology on the production of embroidery clothing.

\begin{tabular}{|c|c|c|c|c|}
\hline $\mathbf{S} / \mathbf{N}$ & Perception Statements & Mean & RII & Rank \\
\hline 1 & $\begin{array}{l}\text { The impact of computer aided design on the machine } \\
\text { embroidery affects the demand and supply of hand } \\
\text { embroidery among consumers }\end{array}$ & 3.70 & 0.740 & 1 \\
\hline 2 & $\begin{array}{l}\text { The reproduction techniques of traditional } \\
\text { embroidery are more tedious than } \\
\text { the machine embroidery }\end{array}$ & 3.68 & 0.736 & 2 \\
\hline
\end{tabular}

Source: Field Work, Adiji (2016).

Observing the types of embroidery practices in the study areas, the machine embroiderers constituted the majority with 185 (78.72\%), while those that were into hand-made embroidery were 50 (21.28\%) of the sampled embroiderers.

Considering the perception of respondents about Computer Aided Design $\mathrm{CAD}$, (Table 2) a greater percentage of respondents agree that machine embroidery affects the demand and supply of handmade embroidery with a relative importance of (RII 0.740) and this is closely aligned with the perceptions of consumers that 'the reproduction techniques of traditional embroidery are more tedious than the machine embroidery' (RII 0.736) ranked first and second respectively in the significance list. This implies that majority of embroiderers in the study areas believe that the use of CAD and machine embroidery will not only make their work less laborious, but will also positively impact on the level of patronage of embroidery.

\section{Conclusion and Recommendation}

The study among other achievements has been able to highlights embroidery as a form of a visual art practice that needs to embrace latest technology to be sustained and remain relevant. The result of the survey carried out in the study areas also reveals the preference of embroiderers for machine embroidery. The result further shows that embroiderers believe that CADs usage in their design process will make their work less cumbersome and increase patronage of their embroidery. This finding therefore implies that research of this manner will continue to help sustains the tradition of embroidery practice. It is expected that the information garnered from the study will further enrich the body of knowledge in the field of embroidery production. 
However, to keep pace with advancement in technology; a dynamic phenomenon, the aspiration towards full automation of embroidery practice should be encouraged. To achieve full automation, there must be sizeable number of embroiderers who have been trained in the use of CADs to make their design. The embroiderers could also employ the services of trained Designers/Artists to help in drawing out the patterns before transferring them on the textile garment.

It is therefore imperative to note that either the embroiderer has decided to use the embroidery machine or the traditional means of needle work, the use of CADs is very valuable and handy in both methods; machine or traditional method of embroidery. This assumption is further buttressed by the fact that the younger generation are no longer interested in the traditional method of mentorship training in embroidery design and production. With the computer technology savvy crop of youths today, there is a need to keep promoting automated embroidery production. This approach is believed to attract the younger generation and keep the art of embroidery alive. There is also a call for synergy between the Nigerian Fashion Designers and CADs developer so that indigenous cultural symbols are created as parts of the cliparts as well as including cultural shapes and forms in the CADs tools.

\section{References}

Adiji, B. E. (2016). Assessment of Embroidery Production on Textile Garments from Selected Cities in South-Western Nigeria. Unpublished Ph.D. Thesis, Akure: Federal University of Technology.

Akinwumi, T. M. (1998). High Fashion in African Dress Machine Embroidery; a Futuristic Model for Lagos Garment Industry. USO; Nigerian Journal of Art.

Aldrich, W. (1997). Metric Pattern Cutting (p. 6). Oxford, UK: Blackwell Science Ltd.

Bilalis N. (2000). Computer Aided Design (CAD). Report Produced for the EC Funded Project Technical University of Crete.

Biney-Aidoo, V., \& Antiaye, E. (2013). Assessing the Production Capacity of the Garment Industry in Ghana in Relation to AGOA Conditions. African Journal of Interdisciplinary Studies, 6, No. 1.

Blier, S. (2005). Microsoft Encarta Reference Lobery. Accessed 30th September 2017.

Burke, S. (2006). Fashion Computering - Design and Techniques and CAD (p. 11). Hong Kong: Everbest Printer.

Heathcote, D. (1979). The Embroidery of Hausa Dress. Unpublished Ph.D. Thesis, Zaria: Department of Fine Art, Ahmadu Bello University.

Ibiwoye, T. I., Ologunwa, T. P., \& Kashim, I. B. (2014). Transiting the Campus Aesthetic Landscape: A Case Study of the Federal University of Technology, Akure, Nigeria. European International Journal of Applied Science and Technology, 1, 70-84.

Leach, A. J. (2002). AutoCAD 2002 Instructor. New York: McGraw-Hill Publishing.

Lemon, J. (2004). Metal Thread Embroidery. Sterling.

Madsen, J., Hartlin, B., Perumalpillai, S., Selby, S., \& Aumônier, S. (2007). Mapping of Evidence on Sustainable Development Impacts That Occur in Life Cycles of Clothing. A Report, London: Department for Environment, Food and Rural Affairs, Environmental Resources Management (ERM) Ltd. 
Mogg, C. C. (2000). Textile Styles; The Art of Using Antique and Exotic Fabrics to Decorate Your Home.

OECD (2004). The New World Map in Textiles and Clothing Adjusting to Change. OECD Policy Brief, October 2004, Paris: Organisation for Economic Cooperation and Development (OECD).

Ogunduyile, S. R. (1985). Aesthetic Values of Hausa Embroidery Caps and Garments in Zaria. Unpublished MA Thesis, Department of Industrial Design, Ahmadu Bello University Zaria.

Oladumiye, B. (2003). Culture, Creativity and National Identity. In K. Filani, A. Azeez, \& A. Emifoniye (Eds.), Perspective on Culture and Creative Art. Nigeria: A Publication of Culture and Creative Art Forum (CCAF) Lagos.

Osunfisan, O. T. P. (1971). Dress Embroidery in Kano City, Nigeria. Unpublished B.A Thesis Fine and Applied Arts Department, Zaria: Ahmadu Bello University.

Tutorials Point (2015). Computer Graphics Tutorial. Copyright by Tutorials Point (I) Pvt. Ltd.

UNIDO (1993). Changing Techno-Economic Environment in the Textile and Clothing Industry: Implications for the Role of Women in Asian Developing Countries, UNIDO PPD. 237 (SPEC), February, 1993. Vienna: United Nations Industrial Development Organization.

Wijayasiri, J., \& Dissanayake, J. (2008). Case Study 3: The Ending of the Multi-Fibre Agreement and Innovation in Sri Lankan Textile and Clothing Industry. OECD Trade Policy Working Paper No. 75, TAD/TC/WP6/PART2/C/FINAL, August, 2008. Paris: Organisation for Economic Cooperation and Development.

Williams \& Agbo (2013). Evaluating the Benefits of Computer Aided-Design. http://www.iiste.org

Wing, I. T. (2010). Creative Embroidery in Contemporary Fashion. A Thesis Submitted in Partial Fulfilment of the Requirements for the Degree of Bachelor of Arts (Honours) in Fashion \& Textiles, Institute of Textiles and Clothing. The Hong Kong Polytechnic University. 